\title{
Molecular and serological detection of Leishmania spp. in captive wild animals from Ilha Solteira, SP, Brazil
}

\author{
Detecção sorológica e molecular de Leishmania spp. em animais selvagens \\ do zoológico de Ilha Solteira, SP, Brasil
}

Márcia Mariza Gomes Jusi ${ }^{1}$; Wilma Aparecida Starke-Buzetti²; Trícia Maria Ferreira de Sousa Oliveira ${ }^{1}$; Michely da Silva Tenório²; Lúcio de Oliveira de Sousaª ${ }^{3}$ Rosangela Zacarias Machado ${ }^{1 *}$

\author{
${ }^{1}$ Departamento de Patologia Veterinária, Universidade Estadual Paulista - UNESP \\ ${ }^{2}$ Departamento de Biologia e Zootecnia, Universidade Estadual Paulista - UNESP \\ ${ }^{3}$ Centro de Conservação de Animais Silvestres de Ilha Solteira, Companhia Energética de São Paulo - CESP
}

Received December 16, 2010

Accepted February 7, 2011

\begin{abstract}
Leishmaniasis is a zoonotic disease that affects 12 million people worldwide. Several mammalian species can serve as a reservoir for this disease. Dogs are the main reservoir for visceral leishmaniasis in urban areas, which has become a serious public health concern in Brazil. The aim of this study was to evaluate the presence of Leishmania spp. in captive wild animals from Ilha Solteira, São Paulo, Brazil. Blood and various tissues samples were collected from animals of five different species: Speothos venaticus, Chrysocyon brachyurus, Cerdocyon thous, Pseudalopex vetulus, and Procyon cancrivorus. Antibodies against Leishmania spp. were detected in three wild canids by indirect fluorescent antibody test (IFAT) and enzyme-linked immunosorbent assay (ELISA). PCR analyses of blood and bone marrow from all animals were negative, but Leishmania DNA was found in the tissues and skin of seropositive animals. Positive PCR samples were also positive for Leishmania donovani complex. Analysis of sequenced PCR products showed similarities with different regions of Leishmania (Leishmania) infantum and Leishmania (Leishmania) chagasi kinetoplastids. Measures to control visceral leishmaniasis in wild animals kept in Brazilian zoos should be established, as no disease control programs are currently available.
\end{abstract}

Keywords: Leishmania spp., wild animals, serology, PCR, Brazil.

\section{Resumo}

Leishmaniose é uma doença zoonótica que afeta cerca de 12 milhôes de pessoas no mundo todo. Várias espécies mamíferas podem servir de reservatório para a doença. Os cáes são considerados os principais reservatórios para a leishmaniose visceral em áreas urbanas, o que tem se tornado um sério problema de saúde pública no Brasil. O objetivo deste trabalho foi avaliar a presença de Leishmania spp. em animais selvagens mantidos no zoológico de Ilha Solteira, São Paulo, Brasil. Foram coletados amostras de sangue e tecidos de cinco espécies diferentes: Speothos venaticus, Chrysocyon brachyurus, Cerdocyon thous, Pseudalopex vetulus, e Procyon cancrivorus. Anticorpos contra Leishmania spp. foram detectados em três canídeos pelo teste de imunofluorescência indireta (RIFI) e pelo ensaio imunoenzimático indireto (ELISA-teste). A análise de PCR das amostras de sangue e medula óssea foi negativa para todas as amostras, mas DNA de Leishmania foi encontrado em tecidos e pele de animais soropositivos. As amostras de PCR positivas também foram positivas para o complexo Leishmania donovani. Análise de sequenciamento dos produtos de PCR mostrou similaridade com diferentes regióes do cinetoplasto de Leishmania (Leishmania) infantum e Leishmania (Leishmania) chagasi. Medidas de controle de leishmaniose visceral em animais selvagens mantidos em zoológicos brasileiros devem ser estabelecidas, uma vez que não há nenhum programa de controle disponível.

Palavras-chave: Leishmania spp., animais selvagens, sorologia, PCR, Brasil.

\footnotetext{
${ }^{*}$ Corresponding author: Rosangela Zacarias Machado 


\section{Introduction}

Leishmaniasis is a zoonotic disease transmitted by sandflies, that affects 12 million people worldwide. The high incidence of leishmaniasis with disfiguring lesions (cutaneous) and sometimes fatal progression (visceral), led the World Health Organization (WHO) to include it among the six most important endemic diseases in the world (WHO, 2010).

Visceral leishmaniasis (VL) is the most severe form of the disease, caused by an obligatory intracellular parasite of monocytes and macrophages in lymphoid organs (GRIMALDI JUNIOR; TESH, 1993). In Brazil, VL is caused by Leishmania (Leishmania) chagasi and transmitted by Lutzomyia longipalpis (ARIAS et al., 1996). It is typically associated with environmental degradation, which forces vector adaptation from wild to urban areas, thereby facilitating human infection (SANTA ROSA; OLIVEIRA, 1997).

Currently, domestic dogs are the main vertebrate reservoir for VL; however, some wild animal species can also serve as reservoirs (ASHFORD, 2000). One such example is the fox Cerdocyon thous, which was found to be a reservoir in Brazil (COURTENAY et al., 1996), but the relevance of other wildlife species is still controversial (DINIZ et al., 2008).

Therefore, we searched for the presence of Leishmania spp. using serological and molecular methods in captive wild animals from a zoo located in Ilha Solteira, São Paulo, Brazil, an area where VL is endemic and affects about $9 \%$ of the 3,798 domestic canid population (ASSIS et al., 2008; TASCA et al., 2009; QUEIROZ et al., 2010).

\section{Materials and Methods}

\section{Animals and sampling}

Fourteen captive wild animals were used in this study: two bush dogs (Speothos venaticus), two maned wolves (Chrysocyon brachyurus), three crab-eating foxes (Cerdocyon thous), one hoary zorro (Pseudalopex vetulus), and six crab-eating raccoons (Procyon cancrivorus). All animals were from the Ilha Solteira Center for Wildlife Conservation, located in Ilha Solteira, São Paulo, Brazil.

Blood and healthy skin samples were collected from all 14 animals and used for serological and polymerase chain reaction (PCR) analyses. Serum samples from the animals were collected twice with an interval of 105 days $\left(T_{0}\right.$ and $\left.T_{105}\right)$, for repeated serology, except three crab-eating raccoons and one bush dog for which only one collection was performed. Bone marrow samples $(1000 \mathrm{~mL}$ each) were also collected from the animals, with the exception of the two bush dogs and one crab-eating fox. Post-mortem samples (25 mg each) of skin lesions, spleen, liver, lymph nodes, and kidney were also collected from two bush dogs and one crab-eating fox because they died with clinical signs of leishmaniasis. One of the two maned wolves also had signs of leishmaniasis, such as onicogriphosis. One of the bush dogs had received a diagnosis of leishmaniasis one year previously and was currently under treatment.
All samples were collected under the Brazilian Institute of Environment and Renewable Natural Resources (IBAMA) license number 15601-1.

\section{Serological analysis}

Serum samples were analyzed by the indirect fluorescent antibody test (IFAT) and enzyme-linked immunosorbent assay (ELISA), as described by Oliveira et al. (2008) for dogs, with some modifications. In samples from $P$. cancrivorus we used anti-raccoon $\operatorname{IgG}\left(\mathrm{KPL}^{\oplus}\right.$ cat $\left.\mathrm{n}^{\circ} 02-32-06\right)$ at a 1:5 dilution for the IFAT, and for the ELISA we used PBS-0.05\% of Tween $80^{\circ}$ (Synth) and peroxidase-linked anti-dog IgG (Sigma ${ }^{\oplus}$ - Cat. n A6792$1 \mathrm{ML})$ at a 1:8,000 dilution. Positive reaction was considered when a fluorescence $>1: 40$ dilution was observed. As negative controls we used sera from 15 dogs from a non-endemic area for VL (Jaboticabal, São Paulo, Brazil), which were negative for leishmaniasis by IFAT and ELISA. As positive controls of IFAT we used sera samples from 15 dogs with VL symptoms and seropositive for Leishmania by IFAT and ELISA, attended at the Veterinary Hospital "Governador Laudo Natel” (School of Agriculture and Veterinary Medicine [FCAV], São Paulo State University [UNESP], Jaboticabal, São Paulo, Brazil) (OLIVEIRA et al. 2008). Due to the difficulties in colleting negative samples from wild species, the discriminating absorbance value (cut-off) was determined as being 2.5 times the mean absorbance value of the negative control.

\section{Leishmania isolation in culture medium}

Bone marrow samples were inoculated in RPMI-1640 medium (Sigma-Aldrich ${ }^{\oplus}$, USA) supplemented with $10 \%$ heatinactivated fetal bovine serum (FBS: Gibco ${ }^{\circ}$, USA) and incubated at $25^{\circ} \mathrm{C}$ in a Corning flask (cat. $\mathrm{n}^{\circ} 430168$ ). Culture was examined every three days for 30 days using inverse optical microscopy to verify parasite replication.

\section{DNA extraction, PCR, and sequencing}

DNA extraction from $200 \mathrm{~mL}$ of blood and bone marrow samples was performed using a QIAamp DNA Blood Mini Kit (Qiagen ${ }^{\circ}$, Santa Clarita, CA, USA). DNA extraction from 25 mg tissue samples was done using a QIAamp Blood and Tissue Kit (Qiagen ${ }^{\circ}$, Santa Clarita, CA, USA).

PCR specific for Leishmania spp. was performed as described by Michalsky et al. (2002) using primers L (5'-GGG GAG GGG CGT TCT GCG AA-3') and L (5'-GGC CCA CTA TAT TAC ACC AAC CCC-3'). For the $L$. donovani complex, PCR was performed using primers $\mathrm{MC}_{1}$ (5'-GTT AGC CGA TGG TGG TCT TG-3') and $\mathrm{MC}_{2}$ (5'-CAC CCA TTT TTC CGA TTT TG-3') as proposed by Cortes et al. (2004). For L. braziliensis, PCR was performed using primers $B_{1}$ (5'-GGG GTT GGT GTA ATA TAG TGG-3') and B (5'-CTA ATT GTG CAC GGG GAG G-3') as described by Reithinger et al. (2000).

Positive samples were subjected to nucleotide sequencing at the Laboratory of Molecular Biology, Department of Technology (FCAV-UNESP, Jaboticabal, São Paulo, Brazil). 
Sequencing reaction was done using the BigDye Terminator Ready Reaction Cycle Sequencing Kit (Perkin-Elmer Applied Biosystems ${ }^{\oplus}$, Courtaboeuf, France) on an ABI PRISM 3100 DNA Analyzer (Applied Biosystems ${ }^{\oplus}$, Courtaboeuf, France). Resulting sequences were analyzed by the BLASTn (Basic Local Alignment Search Tool) program (http://blast.ncbi.nlm.nih.gov/Blast.cgi).

\section{Results}

Serological analyses from serum samples (Table 1) showed that in the first sampling $\left(\mathrm{T}_{0}\right)$, only two out of ten animals were positive by IFAT. These were a crab-eating fox $(1: 40,960)$ and a bush dog $(1: 20,480)$. In the second serum sampling $\left(T_{105}\right)$, the same animals were again positive, but at lower titers, the crabeating fox at 1:5,120 and the bush dog at 1:1,280. A maned wolf, negative in the first sampling, was positive in the second one with final titration of $1: 1,280$. In agreement with the IFAT, the ELISA showed the same animals as positive for Leishmania spp., considering a cut-off of 0.136 . However, there was no growth of Leishmania spp. in culture medium with bone marrow samples of all animals.

Samples from skin lesions, spleen, liver, and lymph nodes collected post-mortem from the seropositive crab-eating fox with clinical signs of leishmaniasis were positive by PCR (Table 1). DNA from Leishmania spp. was also amplified from a healthy skin sample from a maned wolf with clinical signs of the disease, that was also seropositive by IFAT and ELISA (Table 1). However, PCR with DNA extracted from this animal's bone marrow was negative. PCR assays from samples of the bush dog that died with clinical signs of the disease were all negative. The two Leishmania spp. PCR-positive animals were also positive for the $L$. donovani complex, but negative for the L. braziliensis complex.

DNA obtained from the two PCR-positive samples was subjected to nucleotide sequencing and the sequences analyzed by BLASTn. The sequences had a $96 \%$ similarity to the kDNA minicircle sequences of $L$. (L.) chagasi and $L$. (L.) infantum. Sequences were submitted to Genbank and gained accession numbers HM179995 for the sequence from the positive crab-eating fox, and HM179996 for the sequence from the positive maned wolf.

\section{Discussion}

In this study, three captive wild animals were positive by serology: a crab-eating fox (C. thous), a maned wolf (C. brachyurus), and a bush $\operatorname{dog}(S$. venaticus). All blood and bone marrow samples tested by PCR were negative, including samples from seropositive animals. This finding may be explained by the low parasite load observed. On the other hand, tissue samples were positive for the presence of $L$. donovani complex DNA in one crab-eating fox and in one maned wolf. Leishmania DNA was not found in the seropositive bush dog. However, this animal had been under treatment for one year, since receiving a diagnosis of leishmaniasis. Although the animal was serologically positive, the medication may have prevented the detection of the parasite in blood samples, bone marrow, and other tissues (TORRES et al., 2010).
Table 1. Results from serological and molecular tests to detect Leishmania spp. in wild animals from the Ilha Solteira Center for Wildlife Conservation, São Paulo, Brazil.

\begin{tabular}{lccccc}
\hline \multicolumn{1}{c}{ Species } & $\begin{array}{c}\text { Animal } \\
\text { number }\end{array}$ & IFAT & ELISA & PCRb & PCRt \\
\hline Procyon cancrivorus & 1 & - & - & - & - \\
& 2 & - & - & - & - \\
& 3 & - & - & - & - \\
& 4 & - & - & - & - \\
& 5 & - & - & - & - \\
\hline Cerdocyon thous & 6 & - & - & - & - \\
\hline Chrysocyon brachyurus & 1 & - & - & - & - \\
& 2 & + & + & - & + \\
\hline Speothos venaticus & 3 & - & - & - & - \\
\hline Pseudalopex vetulus & 2 & + & + & - & + \\
\hline IFAT: Indirect immunothorescence & 1 & - & - & - & - \\
\hline & 2 & + & + & - & - \\
& 1 & - & - & - & - \\
\hline
\end{tabular}

IFAT: Indirect immunofluorescence antibody test. ELISA: Enzyme-linked immunosorbent assay. PCRb: Polymerase chain reaction with bone marrow and blood samples. PCRt: Polymerase chain reaction with other tissue samples.

Noteworthy is the Leishmania PCR-positive DNA from the healthy skin sample of a maned wolf. Although this animal did not show skin lesions, there was an indication that parasites were present in healthy skin tissue and could potentially be transmitted to sandflies through feeding. Queiroz et al. (2010) showed similar results in asymptomatic domestic dogs 100\% PCR-positive from healthy skin samples. Abranches et al. (1991) observed that 20\% of dogs naturally infected by $L$. (L.) infantum had parasites in the healthy skin regardless of the presence of lesions.

Interestingly, of the five animal species here studied, C. brachyurus and $S$. venaticus, which were both serologically positive for VL, are endangered species (IBAMA, 2010). Crab-eating foxes are considered natural reservoirs of Leishmania, therefore should not develop clinical symptoms (LAINSON et al., 1987). These animals had clinical symptoms of VL that may be a consequence of reduced immune resistance, which is observed in animal zoos, as the constant handling is a stress factor that may impact immunity and favor the development of diseases.

One maned wolf showed parasites in the healthy skin according to PCR analysis. Therefore, apparently healthy wild animals could be acting as reservoirs.

The Ilha Solteira zoo is located near a forest with shaded areas and is protected from wind, thus favoring the presence of mosquitoes and maintenance of animals as VL reservoirs. This may represent a risk for the wild animals kept in this environment to be infected by this parasite from stray dogs, as well as for the zookeepers and visitors.

The translocation of animals between zoos may play a role in the spread of this disease, since apparently healthy infected animals could be placed in zoos where competent vectors are present. Therefore, criteria for exchanging animals between zoos for mating or for other purposes should be established, including 
testing for the presence of biological vectors in these institutions. Also measures to control VL in wild animals kept in Brazilian zoos should be established, as there are no disease control programs for these captive animals.

\section{Acknowledgments}

The authors would like to thank the São Paulo Research Foundation (FAPESP) for its financial support and fellowships, the Brazilian Institute of Environment and Renewable Natural Resources (IBAMA) for authorizing the collection of samples from wild captive animals, and the Ilha Solteira Center for Wildlife Conservation, run by Companhia Energética de São Paulo (CESP).

\section{References}

ABRANCHES, P. et al. Canine Leishmaniasis: pathological and ecological factors influencing transmission of infection. Journal of Parasitology, v. 77, n. 4, p. 557-561, 1991. PMid:1865262. http://dx.doi.org/10.2307/3283159

ARIAS, J. R.; MONTEIRO, P. S.; ZICKER, F. The reemergence of visceral leishmaniasis in Brazil. Emerging Infectious Diseases, v. 2, n. 2, p. 145-146, 1996. PMid:8903218. PMCid:2639817. http://dx.doi. org/10.3201/eid0202.960213

ASHFORD, R. W. The leishmaniases as emerging and reemerging zoonoses. International Journal for Parasitology, v. 30, n. 12-13, p. 1269-1281, 2000. http://dx.doi.org/10.1016/S0020-7519(00)00136-3

ASSIS, J. et al. Leishmaniose visceral canina: novos casos no município de Ilha Solteira, SP. Veterinária e Zootecnia, v. 1, n. 2, p. 72, 2008.

CORTES, S. et al. PCR as a rapid and sensitive tool in the diagnosis of human and canine leishmaniasis using Leishmania donovanis. 1. - specific kinetoplastid primers. Transactions of the Royal Society of Tropical Medicine and Hygiene, v. 98, n. 1, p. 12-17, 2004. http://dx.doi. org/10.1016/S0035-9203(03)00002-6

COURTENAY, O. et al. Visceral leishmaniasis in the hoary zorro (Dusicyon vetulus): a case of mistaken identity. Transactions of the Royal Society of Tropical Medicine and Hygiene, v. 90, n. 5, p. 498-502, 1996. http://dx.doi.org/10.1016/S0035-9203(96)90293-X

DINIZ, S. A. et al. Animal reservoirs for visceral leishmaniasis in densely populated urban areas. The Journal of Infection in Developing Countries, v. 2, n. 1, p. 24-33, 2008.
GRIMALDI JUNIOR, G.; TESH, R. B. Leishmaniases of the New World: current concepts and implications for the future research. Clinical Microbiology Reviews,v. 6, n. 3, p. 230-250, 1993. PMid:8358705. PMCid:358284.

INSTITUTO BRASILEIRO DO MEIO AMBIENTE E DOS RECURSOS NATURAIS RENOVÁVEIS -IBAMA. Lista das Espécies da Fauna Brasileira Ameaçadas de Extinção. Disponível em: <http://www.ibama.gov.br/fauna/downloads/lista\%20spp.pdf>. Acesso em: 6 maio 2010.

LAINSON, R. et al. American visceral leishmaniasis: on the origin of Leishmania (Leishmania) chagasi. Transactions of the Royal Society of Tropical Medicine and Hygiene, v. 81, n. 3, p. 517, 1987. http://dx.doi.org/10.1016/0035-9203(87)90187-8

MICHALSKY, E. M. et al. Assessment of PCR in the detection of Leishmania spp. in experimentally infected individual phlebotomine sandflies (Diptera: Psychodidae: Phlebotominae). Revista do Instituto de Medicina Tropical de Sáo Paulo, v. 44, n. 5, p. 255-259, 2002. http://dx.doi.org/10.1590/S0036-46652002000500004

OLIVEIRA, T. M. F. S. et al. A study of cross-reactivity in serum samples from dogs positive for Leishmania sp., Babesia canis and Ehrlichia canis in Enzyme-Linked Immunosorbent Assay and Indirect Fluorescent Antibody Test. Revista Brasileira de Parasitologia Veterinária, v. 17, n. 1, p. 7-11, 2008. PMid:18554433

QUEIROZ, N. M. G. P. et al. Diagnóstico da leishmaniose visceral canina pelas técnicas de imunoistoquímica e PCR em tecidos cutâneos em associação com a RIFI e ELISA-teste. Revista Brasileira de Parasitologia Veterinária, v. 19, n. 1, p. 34-40, 2010.

REITHINGER, R. et al. Use of PCR to detect Leishmania (Viannia) spp. in dog blood and bone marrow. Journal of Clinical Microbiology, v. 38, n. 2, p. 748-751, 2000. PMid:10655379. PMCid:86194.

SANTA ROSA, I. C. A.;OLIVEIRA, I. C. S. Leishmaniose visceral: breve revisão sobre uma zoonose reemergente. Clínica Veterinária, v. 2, n. 11, p. 24-28, 1997.

TASCA, K. I. et al. Exames parasitológicos, imunoistoquímicos e histopatológicos para detecção de Leishmania chagasi em tecidos esplênicos de cães com leishmaniose visceral. Revista Brasileira de Parasitologia Veterinária, v. 18, n. 1, p. 27-33, 2009.

TORRES, M. et al. Long term follow-up of dogs diagnosed with leishmaniosis (clinical stage II) and treated with meglumine antimoniate and allopurinol. Veterinary Journal, v. 188, n. 3, p. 346-351, 2010. http://dx.doi.org/10.1016/j.tvjl.2010.05.025

WORLD HEALTH ORGANIZATION - WHO. Disponível em: <http://www.who.int/zoonoses/diseases/leishmaniasis/en/>.Acesso em: 6 maio 2010 . 